\title{
SADAR PILAH SAMPAH DENGAN KONSEP 4R (REDUCE, REUSE, RECYCLE, REPLACE) DI DESA GEDONGARUM, KANOR, BOJONEGORO
}

\author{
Yunik'ati $^{*}$, Rio Miftakul Imam ${ }^{2}$, Febri Hariyadi ${ }^{3}$, Ismi Choirotin ${ }^{4}$ \\ ${ }^{1}$ Fakultas Teknik, Universitas Islam Malang \\ email: yunikati369@gmail.com \\ ${ }^{2}$ Fakultas Teknik, Universitas Islam Malang \\ email: rioimam01@gmail.com \\ ${ }^{3}$ Fakultas Teknik, Universitas Islam Malang \\ email: febrihariyadi791@gmail.com \\ ${ }^{4}$ Fakultas Teknik, Universitas Islam Malang \\ email: ismichoirotin@gmail.com
}

\begin{abstract}
Household waste is becoming a common problem in our society. The consumptive lifestyle that is not supported by a good awareness of waste management resulting in increased waste volume. It will give a bad impact on the environment. This community service activity was aimed to provide solutions to waste problems in Gedongarum Village. The programs arranged were: waste sorting through socialization and training activity of $4 R$ concept (Reduce, Reuse, Recycle and Replace), and manufacturing of waste sorting facilities. The results of the evaluation showed that the awareness of the community to the importance of waste sorting and processing increased by $58.7 \%$ and the knowledge on waste management, increased by $76.05 \%$. The effectiveness of the program's success amounted to $71.7 \%$, while $86,9 \%$ of the respondents support the activities to be sustainable.
\end{abstract}

Keywords: waste, reduce, reuse, recycle, replace, sorting

\begin{abstract}
ABSTRAK
Sampah sudah menjadi masalah yang sangat umum dimasyarakat. Pola hidup konsumtif masyarakat yang tidak diimbangi dengan kesadaran pengelolaan sampah yang baik berakibat meningkatnya volume sampah yang bisa berdampak negative pada kebersihan dan kesehatan lingkungan. Kegiatan pengabdian masyaraat ini dilakukan sebagai solusi dari permasalahan tersebut. Dengan melakukan sosialisasi pemilahan sampah konsep 4R (Reduce, Reuse, Recycle dan Replace), membangun sarana pemilahan sampah dan melakukan pelatihan dalam mengolah sampah diharapkan dapat menjadi solusi permasalahan sampah di desa Gedongarum, kecamatan Kanor, kota Bojonegoro. Dari hasil evaluasi setelah kegiatan pengabdian masyarakat ini dilakukan, didapatkan peningkatan kesadaran masyarakat terhadap pentingnya pemilahan dan pengolahan sampah sebesar 58,7\%, pengetahuan masyarakat akan pengelolaan sampah meningkat sebesar 76,05\%, Efektifitas keberlangsungan program sebesar $71,7 \%$, serta masyarakat sangat mendukung keberlangsungan program pengabdian masyarakat ini dengan prosentase $86,9 \%$.
\end{abstract}

Kata Kunci: sampah, reduce, reuse, recycle, replace, pemilahan 


\section{PENDAHULUAN}

Bedasarkan UU No. 18 tahun 2008 tentang pengelolaan sampah, sampah didefinisikan sebagai sisa kegiatan sehari-hari manusia dan atau proses alam yang berbentuk padat. Permasalah sampah ini sudah menjadi masalah nasional dimana perlu pengelolaan yang baik sehingga tidak menimbukan dampak bagi kesehatan masyarakat dan lingkungan (Sulistiyowati, 2006).

Desa Gedongarum Kecamatan Kanor Kabupaten Bojonegoro merupakan daerah yang padat penduduk. Setiap tahun populasi penduduknya terus meningkat hingga saat ini berjumlah 2.757 jiwa, dengan jumlah KK 786 . Sebagai sasaran utama dalam program kami, ibu-ibu PKK beranggotakan 25 orang, dan karang taruna sebanyak 150 pemuda. Pada umumnya pekerjaan mereka sebagai petani, terutama petani padi. Daerah yang ditanami padi cukup luas kisaran 347 hektar. Banyaknya jumlah penduduk dan pola hidup yang konsumtif memicu terjadinya permasalahan lingkungan, yaitu sampah-sampah yang semakin menumpuk, berserakan dan tak terpilah. Masyarakat tidak mempedulikan akan pentingnya kebersihan lingkungan, mereka sibuk dengan urusannya masing-masing demi kelangsungan hidupnya. Padahal kebersihan lingkungan juga sangatlah penting bagi kehidupan (Riswan, 2011).

Permasalahan yang ada di desa Gedongarum yaitu mengenai kesadaran diri pada masyarakat, sudah ada beberapa tempat sampah, namun belum digunakan sesuai fungsinya. Di daerah tersebut juga belum ada pemilahan sampah. Masyarakat membuang sampah masih dalam satu bak sampah tanpa dipisahkan antara organik dan anorganik, bahkan ada yang membuangnya sembarangan. Hal tersebut dikarenakan kurang adanya perhatian pemerintahan desa. Pemerintah tidak pernah mensosialisasikan pentingnya pembuangan dan pemilahan sampah. Serta kurang adanya peran aktif pemuda yang menjadikan banyaknya pengangguran. Dari permasalahan tersebut kami membuat Program Kreativitas Mahasiswa Pengabdian Masyarakat (PKMM) dengan judul "Sadar Pilah Sampah Konsep 4R (Reduce, Reuse, Recycle, Replace) Desa Gedongarum Kanor Bojonegoro" dengan tujuan menanggulangi masalah sampah yang meningkat dan dampaknya pada lingkungan, memberikan kesadaran pada masyarakat untuk mengelola sampah dan menciptakan lapangan kerja dari pegolahan sampah tersebut.

\section{METODE PELAKSANAAN}

Untuk mencapai tujuan dari kegiatan Pengabdian Masyarakat ini maka dilakukan beberapa tahapan pelaksanaan, yaitu:

\section{Koordinasi Tim}

Kegiatan koordinasi dengan tim bertujuan untuk mempersiapkan materi dan segala keperluan untuk bersosialisasi dengan pihak desa beserta masyarakat sasaran, guna mengarahkan masyarakat yang sadar lingkungan secara berkesinambungan dan menyeluruh dibutuhkan sebuah 
media yang menarik serta dianggap menguntungkan bagi masyarakat melalui program pilah sampah yg sudah kami buat.

\section{Koordinasi Dengan Desa}

Kami dengan anggota tim melakukan koordinasi langsung dengan pihak pemerintahan Desa Gedongarum dan ibu PKK serta karang taruna sebagai sasaran utama. Agar program tersebut berjalan lancar sesuai rencana, yang hasilnya dapat dirasakan langsung masyarakat sasaran. Untuk lebih mengenalkan program kami ke pihak tersebut.

\section{Perencanaaan Program}

a. Persiapan sarana dan prasarana

b. Sosialisasi program 4R (Reduce, Reuse, Recycle, Replace)

c. Pelatihan pemilahan sampah, pengomposan dan pembuatan kerajinan

\section{Pelaksanaan Kegiatan}

Aplikasi yang dapat dilakukan dalam konsep reduce ini adalah dengan melakukan kegiatan bank sampah. Setiap rumah diberikan 3 macam bak sampah yaitu warna hijau, kuning dan merah. Dimana warna hijau untuk sampah organik, warna kuning untuk sampah plastik dan warna merah untuk sampah kertas. Dari setiap RT ada perwakilan untuk menjadi petugas bank sampah, mereka setiap harinya bekerja berkeliling mengambil sampah yang berada disetiap rumah warga dan dikumpulkan di TPA (tempat pembuangan akhir). Contoh lain, ketika berbelanja sebaiknya membawa tas berbelanja sendiri sehingga tidak perlu lagi menggunakan teknologi plastik. Jangan sering-sering membeli minuman kemasan botol maupun kaleng.

Konsep reuse diaplikasikan dengan cara, sampah-sampah plastik dibersihkan dahulu sebelum diolah menjadi kerajinan. Setelah bersih, plastik itu kemudian dijahit menjadi berbagai jenis kerajainan dengan bentuk menarik dan ukurannya beragam. Untuk pembuatan kerajinan ini dari ibu-ibu rumah tangga dan remaja perempuan yang masih menganggur, sedangkan pemasarannya bisa via online maupun diperjual belikan secara langsung oleh perwakilan dari karang taruna. Konsep ini akan disambut positif oleh masyarakat Gedongarum,

Konsep recycle dengan mendaur ulang sampah organik menjadi pupuk kompos. Pembuatan kompos ini melibatkan bapak-bapak dan Karang Taruna dalam pengolahannya. Dari setiap RW harus ada perwakilan sebagai pengelolanya.

Dan konsep yang terakhir replace adalah mengganti penggunaan plastik biasa dengan plastik biodegradable yang 100\% ramah lingkungan. Plastik jenis ini lebih eco friendly karena mudah terurai.

Langkah - langkah yang kami lakukan antara lain:

a. Sosialisasi

Sosialisasi terhadap ibu-ibu dan karang taruna sebagai sasaran utama dengan konsep 4R (Reduce, Reuse, Recycle dan Replace).

b. Pembuatan Sarana dan Prasarana 
Pembuatan sarana ini bertujuan membuat segala sesuatu yang dibutuhkan dalam menjalankan program, yaitu sarana pemilahan sampah, tempat pembuangan akhir (TPA) dan sarana pengomposan.

c. Pelatihan

Kami melakukan pelatihan terlebih dahulu ke masyarakat Desa Gedongarum. Kami mengajarkan cara pemilahan sampah, proses pengomposan, dan pembuatan kerajinan

\section{Evaluasi Program}

Evaluasi ini dilakukan selama pelaksanaan berlangsung. Kami melakukan evaluasi setiap 2 minggu sekali. Dengan quisioner dan melihat secara langsung perubahan perilaku masyarakat sekitar dalam hal pemilahan sampah, proses pengomposan dan pembuatan kerajinan.

\section{HASIL DAN PEMBAHASAN}

Hasil yang di capai dari program pengabdian masyarakat sadar pilah sampah konsep 4R (reduce reuse recyle replace) Desa Gedongarum Kanor di kelompokkan berdasar tahapan kegiatan \& pengolahan.

1. Pembuatan sarana pemilahan sampah dengan konsep 4R (reduce reuse recyle replace) di antaranya tempat sampah terpilah (12 set), TPA (tempat pembuangan akhir) 1 unit dan sarana pengomposan ( 2 set). Kegiatan ini didukung dan diterima oleh masyarakat, hal ini terlihat ketika masyarakat berperan aktif dalam pembangunan sarana dan prasarana. Proses pembuatan sarana pemilahan sampah ditunjukkan pada gambar 1 .
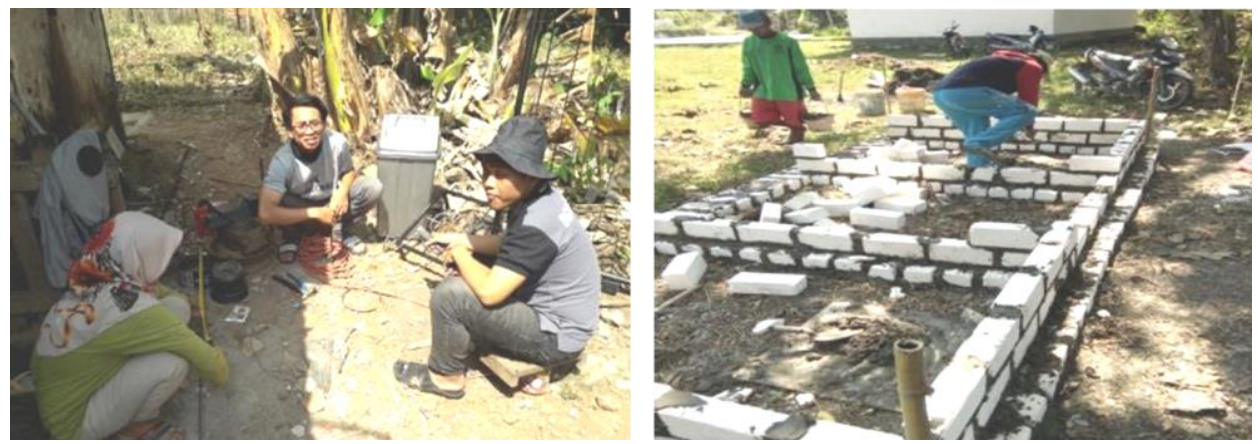

Gambar 1. Proses pembuatan sarana pemilahan sampah

2. Sosialisasi program pilah sampah dilaksanakan pada 12 Mei 2018 di Desa Gedongarum, yang dihadiri oleh \pm 46 peserta berasal dari perangkat desa, ibu-ibu PKK dan karang taruna, ditunjukkan oleh gambar 2. Dengan materi tentang pilah sampah dengan konsep 4R, yang mana peserta merespon dengan baik tentang program ini. 

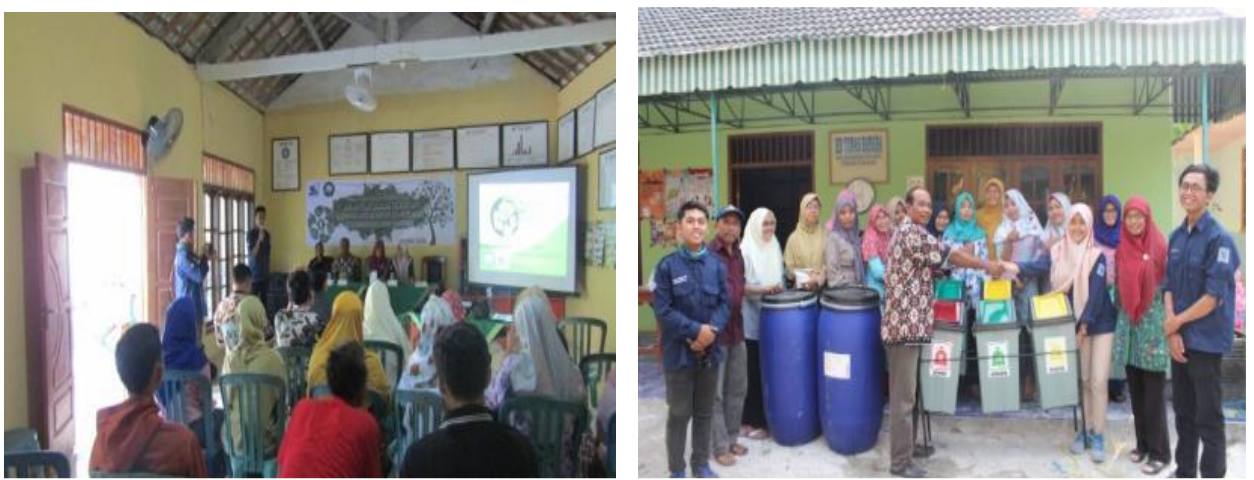

Gambar 2. Kegiatan Sosialisai dan penyerahan sarana pemilahan sampah

3. Pelatihan pembuatan kompos dari sampah organik dan pembuatan kerajinan dari bahan bekas yang bisa didaur ulang. Pelatihan ini diikuti oleh \pm 16 peserta, seperti ditunjukkan oleh gambar 3 . Dalam pelatihan pembuatan kompos, metode pembuatan kompos yang digunakan adalah pengomposan secara aerob. Dalam pelatihan ini dijelaskan sampah apa saja yang bisa dimanfaatkan sebagai bahan kompos, apa saja bahan dan komposisi pembuatan kompos serta aktual proses pembuatan kompos. Tingkat keberlanjutan program pembuatan kompos ini dinilai tinggi, karena selain mengatasi masalah sampah di desa Gedongarum, kompos ini memiliki nilai lebih dimasyarakat dan digunakan sebagai penyubur lahan pertanian. Pelatihan pembuatan kerajinan tangan dari bahan bekas yang bisa didaur ulang, dilakukan dengan memanfaatkan plastik, kertas dan baju bekas. Dari pelatihan ini menghasilkan beberapa hasil kerajinan berupa kotak pensil, hiasan bunga dan beberapa kerajinan hasil kreativitas ibu-ibu desa Gedongarum. Hasil kerajinan tangan saat ini masih dimanfaatkan secara pribadi oleh masyarakat, karena kuantitas bahan baku yang masih terbatas. Dimasa yang akan datang, kegiatan masyarakat untuk menghasilkan kerajinan dari bahan bekas ini diharapkana akan memiliki nilai jual dan dapat meningkatkan perekonomian warga.
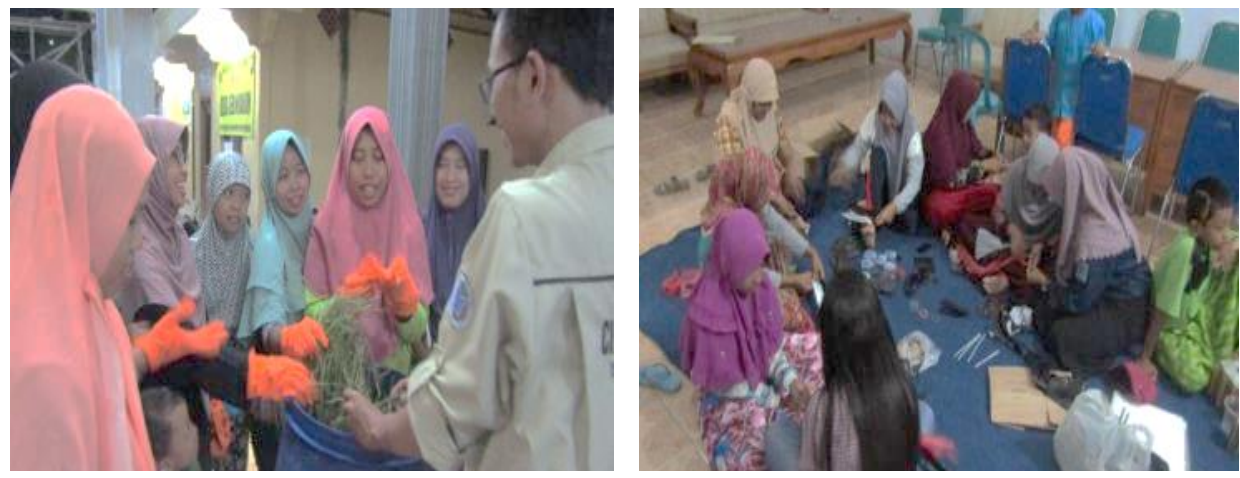

Gambar 3. Pelatihan pengomposan dan pembuatan kerajinan 
Untuk mengetahui tingkat keberhasilan PKM-M ini, maka perlu dilakukan tahapan evaluasi. Tahap evaluasi di lakukan tiga kali, dengan metode pengamatan kondisi aktual serta penyebaran kuisoner. Dari hasil penyebaran kuisioner yang dilakukan sebelum dan sesudah kegiatan PKMM ini serta membandingkannya maka diperoleh hasil seperti yang ditunjukkan oleh grafik 1.

\section{Efektivitas Kegiatan PKMM}

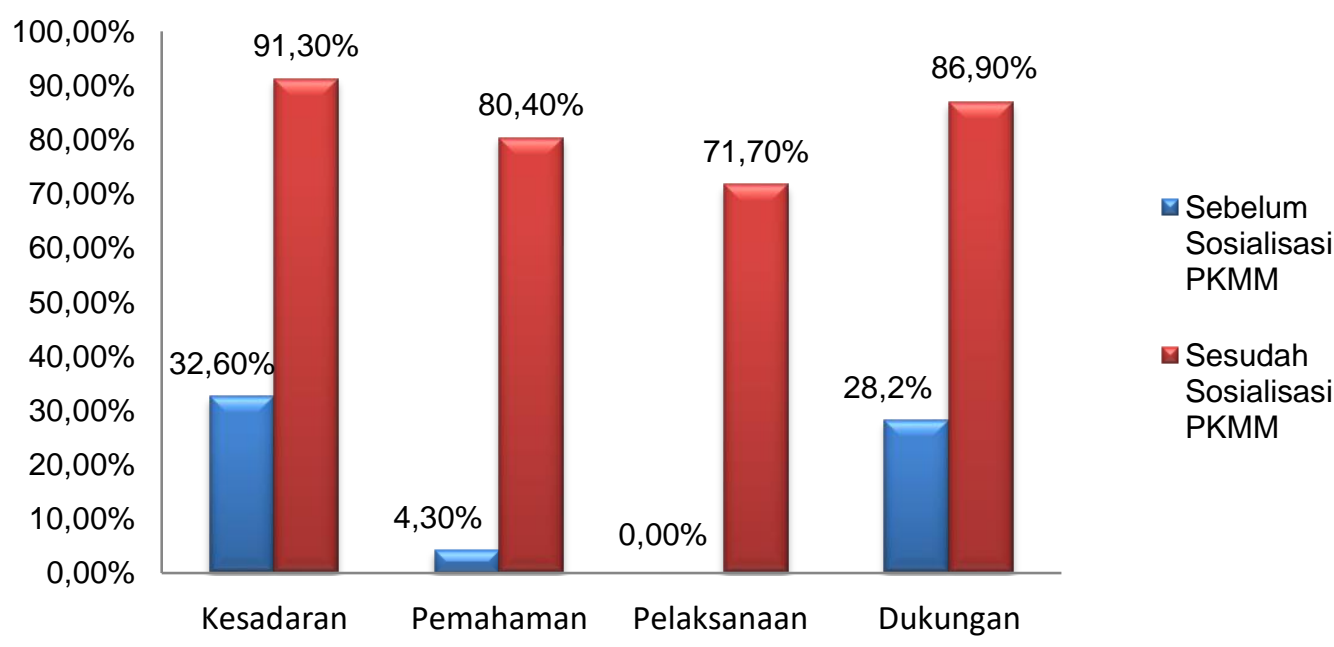

Grafik 1. Efektivitas Kegiatan Pengabdian Masyarakat

Dari hasil evaluasi yang ditunjukkan oleh grafik 1, bisa dilihat bahwa kesadaran masyarakat akan pentingnya pengolahan sampah setelah terselenggaranya kegiatan pengabdian masyarakat ini meningkat dari 32,60\% menjadi $91,30 \%$. Pemahaman masyarakat tentang pemilahan sampah dengan konsep 4R serta pelatihan yang diberikan meningkat dari $4,30 \%$ menjadi $80,40 \%$. Pelaksanaan program yang berupa pemilahan dan pengolahan sampah berjalan $71,70 \%$. Dukungan masyarakat terhadap keberlangsungan dan keberlanjutan program pemilahan sampah dengan konsep $4 \mathrm{R}$ ini meningkat dari $28,29 \%$ menjadi $86,90 \%$.

Dari keseluruhan hasil evaluasi berupa kuisioner dan pengamatan, bisa dilihat bahwa prosentase pelaksanaan kegiatan Pengabdian Masyarakat sadar pilah sampah dengan konsep $4 \mathrm{R}$ ini kurang signifikan yaitu sebesar $71,70 \%$, hal ini dikarenakan masih sangat minimumnya jumlah sarana pemilahan jika dibandingkan dengan jumlah keluarga di Desa Gedongarum, sehingga progam berjalan kurang maksimal. Selain itu tingkat pemahaman masyarakat juga masih kurang, terbatas pada peserta sosialisasi dan pelatihan saja. Berdasarkan hasil evaluasi dan demi keberlanjutan program pengabdian masyarakat ini, maka kami melakukan langkah sebagai berikut: 
1. Pengusulan pada perangkat desa untuk menganggarkan dana untuk menambah ketersediaan sarana pemilahan sampah disetiap rumah.

2. Pembuatan SOP tentang proses pemilahan sampah dan cara pengomposan

\section{KESIMPULAN}

Kegiatan pengabdian masyarakat dengan judul "Sadar Pilah Sampah Konsep 4R (Reduce, Reuse, Recycle, Replace) Desa Gedongarum, Kanor Bojonegoro" sangat bermanfaat bagi masyarakat, karena menjadi solusi untuk pengelolaan sampah yang jumlahnya semakin meningkat, memberikan dampak positif dari aspek sosial, lingkungan dan ekonomi.

\section{UCAPAN TERIMA KASIH}

Kegiatan pengabdian masyarakat ini berjalan dengan pendanaan dari DIKTI untuk Program Kreativitas Mahasiswa Pengabdian Masyarakat.

\section{DAFTAR RUJUKAN}

AUndang-undang pengelolaan sampah Nomor 18, tahun 2008 Sulistyowati, 2006, Analisis mengenai dampak lingkungan (AMDAL) dalam pengelolaan sampah kota. Program Pasca Sarjana Universitas Muhammadiyah Surakarta. Skripsi.

Riswan, Henna Rya, S, dan Agus, H, 2011, 'Pengelolaan sampah rumah tangga di kecamatan daha selatan', Jurnal Ilmu Lingkungan, Vol. 9, no. 1, hh. 35-37

Kusmiyah, Imah Luluk. 2018. Penyuluhan 4r (Reduce, Reuse, Recycle, Replace) dan Kegunaan Bank Sampah Sebagai Langkah Menciptakan Lingkungan yang Bersih dan Ekonomis di Desa Mojowuku Kabupaten Gresik. Jurnal Pengabdian LPPM Untag Surabaya, Vol. 03, no. 01, hh 22-28 